\title{
Human Capital Development, Infrastructural Development and Industrial Sector Productivity in Nigeria
}

\author{
Oluwafemi S. Enilolobo \\ Department of Economics, Accounting and Finance, \\ Bells Univ. of Tech., Ota, Nigeria \\ Olamide Sodeinde \\ Department of Economics, Accounting and Finance, \\ Bells Univ. of Tech., Ota, Nigeria
}

\begin{abstract}
This study examines relationship between human capital development, infrastructural development and industrial sector in Nigeria for the period 1991 through 2014. The objective of the study is to identify some critical economic and social factors that influence industrial sector productivity in Nigeria. To ascertain the relationship between our variables of studies, secondary source of data was employed and extracted from World Development Indicators. Using an Ordinary Least square (OLS) estimation technique, the study established that human capital development has positive and significant effect on industrial sector productivity while infrastructural development has positive but insignificant effect on industrial sector productivity in Nigeria. Thus, the study recommends effective negotiation of debt relief from Paris club and other foreign debt to enable the government have excess funds to invest on pro-poor intervention project, transparency in governance and implementation of fiscal budget with post evaluation.
\end{abstract}

Keywords: Human Capital Development, Infrastructural Development, Industrial Sector productivity

\section{INTRODUCTION}

A developmental focused economy must upgrade its infrastructure and concurrently improve the quality of human capital if it is to achieve sustainable economic growth through improved productivity of industrial sector; this is contained in the report of Asian development Bank (ADB) on the country's growth prospects. Economist Theodore Schultz invented the term (human capital) in the 1960s to reflect the value of our human capacities. He believed human capital was like any other type of capital; it could be invested in through education, training and enhanced benefits that will lead to an improvement in the quality and level of production.

According to Todaro and Smith (2011), human capital is productive investments embodied in human persons, including skills, abilities, ideals, health, and locations, often resulting from expenditures on education, on-the-job training programs and medical care. Improvements in productive efficiency from investment in education raise the return on a lifesaving investment in health. In 2010, the OECD (the Organization of Economic Co-operation and Development) encouraged the governments of advanced economies to embrace policies to increase innovation and knowledge in products and services as an economical path to continued prosperity. International policies also often address human capital flight, which is the loss of talented or trained persons from a country that invested in them, to another country which benefits from their arrival without investing in them. 
Infrastructure is frequently defined as a set of basic physical and organizational structures and facilities required for operation of an economy. Infrastructure can be divided into economic infrastructure (transport, telecommunication, energy provision and sewage) and social infrastructure (law enforcement, security provision, education and health system. The economic infrastructure Development will go a long way in contributing to both economic growth and economic development (Srinivasu \& Rao, 2013).

How is this human capital and infrastructural development of importance to developing countries, particularly, Nigeria? Economic development of Nigeria can be facilitated and accelerated by the presence of infrastructure. If these facilities and services are not in place, development will be very difficult and in fact can be likened to a very scarce commodity that can only be secured at a very high price and cost (Srinivasu \& Rao, 2013).

Large number of empirical studies did not analysis human capital development, infrastructural development and industrial sector productivity in a single study, however, some of the empirical studies have shown the relationship between two of the variables (taking either human capital development or infrastructural development as an explanatory variable to economic growth or industrial sector performance).

Empirical studies on Infrastructural development and Industrial sector productivity have shown that public capital has important explanatory power for why some countries have managed to industrialize, while others have not (Anders 2009).Focusing exclusively but critically on the power supply situation in Nigeria, Emeka (2008) argued that despite huge funds government had committed into the power sector between (1999-2007), Nigeria with population of over 140 million was only able to generate less than 3,000 MW as against over $10,000 \mathrm{MW}$ needed to transform the economy of the country. He further identified several causes of this inadequate power supply and argued that this precarious situation has serious negative implications for the operations of industrial sector in the country, as most organizations spent fortunes generating their own power. This situation represents a major setback on the country's quest for industrial development.

On human capital development and industrial sector productivity; empirical studies have it that firm performance in relation to human capitals should not be regarded as a phenomenon that only adds 'more zeros' in a firm's profits; it is rather transforming the entire workforce as the most 'valuable assets' in order for the organization to pave ways for greater achievements via innovativeness and creativity. However, government expenditure on education maintained a positive long run relationship with index of industrial production while government expenditure on health and Gross Capital Formation exhibited long run negative relationship with the dependent variable (Simon, 2012), strong positive relationship in banking industry (Oyinlola et al., 2014).

After this introduction section, sections 2 and 3 present the summary of empirical literature review and research methodology respectively. In sections 4 and 5, the empirical results, conclusion and policy recommendations are discussed.

\section{EMPIRICAL LITERATURE REVIEW ON HUMAN CAPITAL DEVELOPMENT, INFRASTRUCTURAL DEVELOPMENT AND INDUSTRIAL SECTOR PRODUCTIVITY}

Evaluating the relationship among the variables of study, one can conclude that empirical results were not having uniform inferences. For example, Government community service infrastructure spending, private infrastructure investment, broad money supply, and total population, exert positive influence on economic growth (Adesoye 2014) but on a contrary, 
both government expenditure on administration and government expenditure on economic services have negative relationships with industrial productivity (Tawose 2012).Very many of the empirical studies supported the fact that human capital development has a positive and significant influence on productivity of industrial sector, the only point of clarification was that - government expenditure on education maintained a positive long run relationship with index of industrial production while government expenditure on health and Gross Capital Formation exhibited long run negative relationship with index of Industrial production (Simon 2012).

The summary of empirical literature reviewed on diseases, longevity and labour productivity is shown in Table 1: 
Table 1: Summary of Empirical Literature Review

Human Capital Development, Infrastructural Development and Industrial Sector Productivity in Nigeria

\begin{tabular}{|c|c|c|c|c|c|}
\hline $\begin{array}{l}\text { Author(s) } \\
\text { and Year }\end{array}$ & Title/Objective & Scope & Methodology & Findings & Comment \\
\hline $\begin{array}{l}\text { Akintoye et } \\
\text { al. (2013) }\end{array}$ & $\begin{array}{l}\text { The role of human } \\
\text { capital in } \\
\text { industrial } \\
\text { development: The } \\
\text { Nigerian Case } \\
(1980-2010)\end{array}$ & $\begin{array}{l}\text { The scope of } \\
\text { study was } \\
\text { limited to } \\
\text { Nigeria within } \\
\text { the period of } \\
1980 \text { through } \\
2010\end{array}$ & $\begin{array}{l}\text { Time series } \\
\text { data covering } \\
\text { the period } \\
\text { between } 1980 \\
\text { and } 2010 \text { were } \\
\text { used with an } \\
\text { appropriate } \\
\text { econometric } \\
\text { technique } \\
\end{array}$ & $\begin{array}{l}\text { Human capital has to a } \\
\text { large extent impacted on } \\
\text { industry value-added, but } \\
\text { in terms of output } \\
\text { generated industrially, the } \\
\text { effect of human capital } \\
\text { remains low in Nigeria. }\end{array}$ & $\begin{array}{l}\text { Inconsistency of } \\
\text { the findings may } \\
\text { be as a result of } \\
\text { inadequate } \\
\text { explanatory } \\
\text { variables. }\end{array}$ \\
\hline $\begin{array}{l}\text { Simon -Oke } \\
\text { O. Olayemi } \\
(2012)\end{array}$ & $\begin{array}{l}\text { Human Capital } \\
\text { Investment and } \\
\text { Industrial } \\
\text { Productivity in } \\
\text { Nigeria. }\end{array}$ & $\begin{array}{l}\text { secondary data } \\
\text { spanned } \\
\text { through } 1978 \\
\text { to } 2008\end{array}$ & $\begin{array}{l}\text { Co-integration } \\
\text { and Error } \\
\text { Correction } \\
\text { Mechanism } \\
\text { (ECM) was } \\
\text { employed while } \\
\text { Granger } \\
\text { causality test } \\
\text { was also } \\
\text { adopted as a } \\
\text { supplementary } \\
\text { estimation } \\
\text { method }\end{array}$ & $\begin{array}{l}\text { Government expenditure } \\
\text { on education maintained a } \\
\text { positive long run } \\
\text { relationship with index of } \\
\text { industrial production } \\
\text { while government } \\
\text { expenditure on health and } \\
\text { Gross Capital Formation } \\
\text { exhibited long run } \\
\text { negative relationship with } \\
\text { index of Industrial } \\
\text { production }\end{array}$ & $\begin{array}{l}\text { Tendency of } \\
\text { having qualitative } \\
\text { variables having } \\
\text { significance } \\
\text { influence cannot } \\
\text { be ruled out. }\end{array}$ \\
\hline $\begin{array}{l}\text { Oyinlola et } \\
\text { al. (2014) }\end{array}$ & $\begin{array}{l}\text { An Empirical } \\
\text { Analysis of } \\
\text { Humana Capital } \\
\text { Development and } \\
\text { Organizational } \\
\text { performance in } \\
\text { Banking sector: A } \\
\text { Nigerian } \\
\text { experience }\end{array}$ & $\begin{array}{l}\text { branches of } \\
\text { four selected } \\
\text { banks spread } \\
\text { across the State }\end{array}$ & $\begin{array}{l}\text { Descriptive } \\
\text { Analysis }\end{array}$ & $\begin{array}{l}\text { Significant relationship } \\
\text { exists between human } \\
\text { capital development and } \\
\text { organizational } \\
\text { performance in the } \\
\text { banking industry }\end{array}$ & $\begin{array}{l}\text { Selected number } \\
\text { of banks may not } \\
\text { be adequate } \\
\text { representative for } \\
\text { forming } \\
\text { substantive } \\
\text { inferences }\end{array}$ \\
\hline $\begin{array}{l}\text { Anochiwa et } \\
\text { al. (2014) }\end{array}$ & $\begin{array}{l}\text { Human Capital, } \\
\text { Infrastructure and } \\
\text { economic growth } \\
\text { in Nigeria: An } \\
\text { empirical } \\
\text { evidence. }\end{array}$ & $\begin{array}{l}\text { Nigeria with } \\
\text { data spanning } \\
\text { between 1970- } \\
2010\end{array}$ & $\begin{array}{l}\text { A cointegration } \\
\text { and error- } \\
\text { correction } \\
\text { modelling } \\
\text { framework }\end{array}$ & $\begin{array}{l}\text { Human capital is found to } \\
\text { be positive and statistically } \\
\text { significant to growth. The } \\
\text { infrastructure variable } \\
\text { (electricity) is positive but } \\
\text { statistically insignificant }\end{array}$ & $\begin{array}{l}\text { Possibility for OLS } \\
\text { inconsistency due } \\
\text { to omitted } \\
\text { variable }\end{array}$ \\
\hline $\begin{array}{l}\text { Anders et al } \\
(2009)\end{array}$ & $\begin{array}{l}\text { Public Capital, } \\
\text { Infrastructure and } \\
\text { Industrial } \\
\text { Development }\end{array}$ & $\begin{array}{l}57 \text { advanced } \\
\text { and developing } \\
\text { countries for } \\
\text { the time period } \\
\text { of } 1970 \text { to } \\
2000\end{array}$ & $\begin{array}{l}\text { Ordinary Least } \\
\text { Square }\end{array}$ & $\begin{array}{l}\text { public capital has } \\
\text { important explanatory } \\
\text { power for why } \\
\text { some countries have } \\
\text { managed to industrialize, } \\
\text { while others have not }\end{array}$ & $\begin{array}{l}\text { Stages of } \\
\text { development } \\
\text { cannot be } \\
\text { undermined in } \\
\text { assessing the } \\
\text { explanatory power } \\
\text { of public capital }\end{array}$ \\
\hline $\begin{array}{l}\text { Tawose } \\
(2012)\end{array}$ & $\begin{array}{l}\text { Effects of public } \\
\text { expenditure on } \\
\text { industrial sector } \\
\text { productivity in } \\
\text { Nigeria }\end{array}$ & $\begin{array}{l}\text { Nigeria with } \\
\text { data spanning } \\
\text { between } 2000 \\
\text { and } 2009\end{array}$ & $\begin{array}{l}\text { Ordinary least } \\
\text { square multiple } \\
\text { regression }\end{array}$ & $\begin{array}{l}\text { Both government } \\
\text { expenditure on } \\
\text { administration and } \\
\text { government expenditure } \\
\text { on economic services have } \\
\text { negative relationships with } \\
\text { industrial productivity. }\end{array}$ & $\begin{array}{l}\text { Appropriate } \\
\text { consideration of } \\
\text { resource } \\
\text { allocation pattern } \\
\text { in Nigerian } \\
\text { economy is sine } \\
\text { quo none. }\end{array}$ \\
\hline $\begin{array}{l}\text { Georges D. } \\
\text { Mbondo } \\
\text { (2014) }\end{array}$ & $\begin{array}{l}\text { Public Spending } \\
\text { on Infrastructures } \\
\text { and Productive } \\
\text { Efficiency in Sub- } \\
\text { Saharan Africa: An }\end{array}$ & $\begin{array}{l}27 \text { sub - } \\
\text { Saharan Africa } \\
\text { countries } \\
\text { grouped into } \\
\text { three economic }\end{array}$ & $\begin{array}{l}\text { Ordinary Least } \\
\text { Square }\end{array}$ & $\begin{array}{l}\text { Public infrastructure } \\
\text { spending on productive } \\
\text { efficiency is positive in } \\
\text { sub-Saharan Africa as a } \\
\text { whole. }\end{array}$ & $\begin{array}{l}\text { There is tendency } \\
\text { for OLS biased }\end{array}$ \\
\hline
\end{tabular}




\begin{tabular}{|c|c|c|c|c|c|}
\hline & $\begin{array}{l}\text { Analysis from the } \\
\text { Stochastic } \\
\text { Production } \\
\text { Frontier on Panel } \\
\text { Data }\end{array}$ & $\begin{array}{l}\text { zones, namely } \\
\text { CEMAC, } \\
\text { ECOWAS and } \\
\text { COMESA with } \\
\text { data spanning } \\
\text { between } 1990 \\
\text { and } 2012\end{array}$ & & & \\
\hline $\begin{array}{l}\text { Adesoye } \\
(2014)\end{array}$ & $\begin{array}{l}\text { Infrastructural } \\
\text { Financing in } \\
\text { Nigeria: Growth } \\
\text { Implications }\end{array}$ & $\begin{array}{l}\text { Nigeria } \\
\text { between } \\
1970 \text { and } 2010\end{array}$ & $\begin{array}{l}\text { The ordinary } \\
\text { least square } \\
\text { (OLS) method }\end{array}$ & $\begin{array}{l}\text { Government community } \\
\text { service infrastructure } \\
\text { spending, private } \\
\text { infrastructure investment, } \\
\text { broadmoney supply, and } \\
\text { total population, exert } \\
\text { positive influence } \\
\text { on economic growth }\end{array}$ & $\begin{array}{l}\text { Possibility for OLS } \\
\text { inconsistency due } \\
\text { to omitted } \\
\text { relevant variables }\end{array}$ \\
\hline $\begin{array}{l}\text { Olayinka } \\
\text { (2011) }\end{array}$ & $\begin{array}{l}\text { Intellectual Capital } \\
\text { and } \\
\text { Business } \\
\text { Performance: } \\
\text { Evidence } \\
\text { from } \\
\text { Nigeria }\end{array}$ & $\begin{array}{l}\text { A sample of } \\
\text { thirty-two (32) } \\
\text { quoted } \\
\text { companies for } \\
\text { the period } \\
\text { 2009year end } \\
\text { was used }\end{array}$ & $\begin{array}{l}\text { Regression } \\
\text { Method }\end{array}$ & $\begin{array}{l}\text { Intellectual capital hasa } \\
\text { positive and significant } \\
\text { relationship with the } \\
\text { performance of business } \\
\text { organizations in Nigeria. }\end{array}$ & $\begin{array}{l}\text { Focus on a year } \\
\text { result may not be } \\
\text { adequate in } \\
\text { making general } \\
\text { inferences. }\end{array}$ \\
\hline Ben (2011) & $\begin{array}{l}\text { Building Human } \\
\text { Capital for } \\
\text { Sustainable } \\
\text { Economic } \\
\text { Development in } \\
\text { Nigeria }\end{array}$ & $\begin{array}{l}\text { Various } \\
\text { segments of the } \\
\text { Nigerian } \\
\text { economy }\end{array}$ & $\begin{array}{l}\text { Descriptive } \\
\text { Analysis }\end{array}$ & $\begin{array}{l}\text { The study revealed that } \\
\text { the sector lags behind in all } \\
\text { the indicators used to } \\
\text { assess its effectiveness }\end{array}$ & $\begin{array}{l}\text { More reliable } \\
\text { inferences may be } \\
\text { attained using } \\
\text { modern } \\
\text { econometric } \\
\text { methods. }\end{array}$ \\
\hline $\begin{array}{l}\text { Geraldine } \\
\text { (2012) }\end{array}$ & $\begin{array}{l}\text { Relationship } \\
\text { between Human } \\
\text { Resource Effects } \\
\text { and Productivity } \\
\text { in the Nigerian } \\
\text { Transport } \\
\text { Industry }\end{array}$ & $\begin{array}{l}\text { Primary Data: } \\
\text { Parastatals and } \\
\text { transport firms } \\
\text { of all modes in } \\
\text { Nigeria }\end{array}$ & $\begin{array}{l}\text { Descriptive } \\
\text { Analysis }\end{array}$ & $\begin{array}{l}\text { Majority of the workers in } \\
\text { the transport industry } \\
\text { were unskilled with only a } \\
\text { few workers possessing } \\
\text { higher degrees, despite the } \\
\text { positive relationship } \\
\text { observed between human } \\
\text { resource effect and the } \\
\text { productivity }\end{array}$ & $\begin{array}{l}\text { One sector of the } \\
\text { economy may not } \\
\text { give a general } \\
\text { view for the whole } \\
\text { sectors. }\end{array}$ \\
\hline
\end{tabular}

\section{Source: Authors' compilation}

\section{RESEARCH METHODOLOGY}

\section{Theoretical Framework}

In this study, we start with a simple Cobb Douglas production function of output (X) with physical capital stock $(K)$ and labour force $(L)$ as the two basic inputs. The Labour force can be further replaced with stock of human capital $(\mathrm{H})$ since we assume the labour input to be conditioned for the average level of education.

$$
Q_{t}=A K_{t}^{\alpha} L_{t}^{\beta}
$$

Where the sum of $\alpha$ and $\beta$ is one, and $\alpha$ and $\beta$ are the efficiencies of capital and labour respectively. $A$ is the average level of technology common to capital and labour. Taking after the work of Tomasz (2012), the general production function is given by

$$
Q_{t}=I^{\lambda} K^{\alpha}(A L)^{1-\alpha}
$$

where $\mathrm{Q}$ is the aggregate output of a country, A an index of the level of technology that is exogenous to individual firms within countries, I is an index of the quality of infrastructure that 
is also exogenous to individual firms, $\mathrm{K}$ the stock of aggregate physical capital, and $\mathrm{L}$ the labour force. Infrastructure externality could be positive, negative or neutral. Thus no restriction is set on parameter $\lambda$ because it can assume negative, neutral and positive values. The general production function shows constant returns to scale as long as we keep Infrastructure simple. However, accumulation human capital through education system generates an externality given by:

$$
\mathrm{L}=\mathrm{h}^{\Omega}
$$

The subscript represents externality for level of education while $\mathrm{h}$ on itself is the level of education. Then we substitute equation 3 into equation 2 as thus

$$
X_{t}=I^{\lambda} K^{\alpha}\left(A h^{\Omega}\right)^{1-\alpha}
$$

t infrastructure as a simple, exogenous efficiency-adjusting parameter.

Tomasz (2012) also referred to Mincerian tradition the average level of education may be specified as a function of average schooling years and average years of experience (Bils and Klenow 2000). For simplicity, potential non - linear is omitted.

Accordingly:

$$
\mathrm{h}=\mu \varepsilon^{\theta \mathrm{AYSand} \rho \mathrm{AYC}}
$$

where $\mu$ is a positive constant, AYS gives average years of schooling and AYE represents average years of working experience in a given country/region. Parameters $\theta$ and $\rho$ represent average individual private returns to schooling and experience respectively. Substituting (5) into and (4) and dividing both sides by L we obtain the formula for real output per human capital $\mathrm{x}$ :

$$
x=I^{\lambda} K^{\alpha}\left(A h^{1 /}\right)^{1-\alpha} L^{-1}
$$

The equation above is re-expressed fully in equation 7 as thus:

$$
\mathrm{X}=\mathrm{I}^{\lambda} \mathrm{K}^{\alpha}\left[\mathrm{A}\left(\mu \varepsilon^{\theta \mathrm{AYS} \text { and } \rho \mathrm{AYC}} \mathrm{h}\right)\right]^{1-\alpha} \mathrm{L}^{-1}
$$

Equation 6 is the industry production function expressed for labour productivity.

\section{Model Specification}

In specifying a model that will explain the interrelationship between human capital development, infrastructural development and industrial sector productivity, there is the possibility of encountering endogeneity problem. That is, any of the three variables may correlate with the error term when specified as explanatory variable. Thus, industrial sector productivity will be treated as endogenous variable in the model while other variables are treated exogeneity

\section{Relationship between Human Capital, Infrastructural Development and Industrial sector productivity in Nigeria}

To establish relationship between the three contending variables above, a human and physical production function in which industrial sector productivity is treated as regressand is formulated. The model is formulated to explore physical capital $(\mathrm{K})$ and human capital $(\mathrm{H})$ complementarity impact on long-run economic growth, however, the model is modified to fit the purpose of our study. More so, some factors have been found to be relevant in explaining 
the growth of industrial sector productivity but within the range of identifying main determinants (human capital and infrastructural development) and they include:

1. Education and Health - Tadaro and Smith (2011) stated that education plays a key role in the ability of a developing country to absorb modern technology and to develop the capacity for self-sustaining growth and development. Moreover, health is prerequisite for increases in productivity, and successful education relies on adequate health as well.

2. Energy provision will be considered as a factor under economic infrastructure while education and health is synonymous to social infrastructure (also factor considered under human capital)

The model assumed constant returns to each factor. It is implicitly specified as follow;

$$
\operatorname{INDVA}_{t}=f\left(\mathrm{H}_{\mathrm{t}}, \mathrm{I}_{\mathrm{t}}\right)
$$

Where INDVA is the productivity level of industrial sector, $\mathrm{H}$ is the human capital development and I, is the level of Infrastructure.

This can be further expanded into more component variables within the range of the main determinants as thus

$$
\operatorname{INDVA}_{t}=f\left(G^{2} R_{t}, H_{t}, G_{t}\right) \text {.. }
$$

Where:

INDVA = productivity level of industrial sector.

GER = Education level measured by gross primary school enrolment;

$\mathrm{HT}$ = the health factor; improved sanitation facilities (SANF) and access to clean water (WATRs)

$\mathrm{G}=$ Provision of energy and basically measured electricity production from hydroelectric sources (ELEC)

$t$ periods of time.

Explicitly, equation 9 could be stated thus;

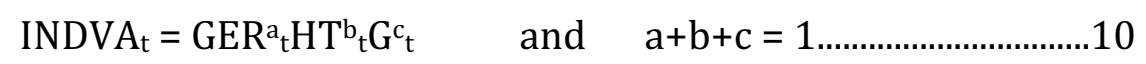

Where $a, b$, and $c$ are vectors of parameters for education, health and energy provision respectively. By log-linearizing equation 3 using natural logarithm, we have;

$$
\operatorname{lnINDVA} A_{t}=\alpha+a \ln \mathrm{GER}_{\mathrm{t}}+\mathrm{b}_{1} \ln \mathrm{SANFt}+\mathrm{b}_{2} \ln \mathrm{WATRst}_{+} \mathrm{c} \ln \mathrm{ELEC}_{\mathrm{t}}+\mu_{\mathrm{t}}
$$

where $\alpha$ and $\mu_{t}$ are the intercept and error term respectively, $b_{1}+b_{2}=b$ for HTtwhich comprises $\left(\mathrm{SANF}_{\mathrm{t}}+\mathrm{WATR} \mathrm{s}_{\mathrm{t}}\right)$. Table 2 shows the apriori expectation.

Table 2: Apriori Expectation of the Impact of Exogenous variables on Industrial Productivity

\begin{tabular}{|l|l|l|l|}
\hline Productivity & GER $(+)$ & & \\
\hline & $H T(+)$ & SANF $(+)$ & WATRs (+) \\
\hline & ELEC $(+)$ & & \\
\hline
\end{tabular}

NB: All the signs in parentheses represent the apriori expectation relative to industrial productivity. 


\section{Estimation Techniques}

Estimating equation 4 using ordinary least square (OLS) techniques, there is every tendency that we face some challenges on endogeneity issue, correlation between the disturbances (autocorrelation), unequal variances of error terms (heteroskedasticity) and correlation between the lagged dependent variables and the error term, hence making OLS estimator biased and inconsistent. These identified problem can be reduced to a reasonable level if not eliminated by using Generalized Least Squares (GLS), as it takes such information into account explicitly and therefore capable of producing estimators that are BLUE.

In this study, GLS technique is adopted. A transformation of equation 4 from OLS to GLS is executed on the assumption of heteroscedastic variances $\delta^{2}$ are known, hence divide all through by $\delta$ to obtain (lag introduced)

$\operatorname{lnINDVA} A_{t} / \delta=\alpha \operatorname{lnINDVA} A_{t-1}+a \ln \mathrm{GER}_{\mathrm{t}} / \delta+\mathrm{b}_{1} \ln \mathrm{SANFT}_{\mathrm{t}} / \delta+\mathrm{b}_{2} \ln \mathrm{WATR}_{\mathrm{t}} / \delta+\mathrm{c} \ln \mathrm{ELEC}_{\mathrm{t}} / \delta+$ $\mu_{\mathrm{t}} / \delta$. 12

\section{Sources of Data and Measurement of Variables}

The data is sourced from World Development Indicators (WDI) online database published by World Bank organization. Time series data spanning from 1991 and 2014 were used. The choice of these explanatory variables and the periods covered were informed by the extent of data availability.

In this study, the variables of interest are Level of Industrial Sector Productivity (INDVA) which is the industry value added, education level (GER) considering enrolment at primary level, The health factor(HT) looking at the improved sanitisation facilities (SANF), access to clean water (WATRs), Provision of energy (G) which is the electricity production from hydroelectric sources(ELEC).

\section{Descriptive Statistics}

\section{EMPIRICAL FINDINGS}

The empirical analysis of this study starts from descriptive statistics of variables used in the study with the aim of verifying their characteristics; hence, graphical presentation below reveals the relationship between industry value in Nigeria and various independent variables as adopted in the study between 1991 and 2014 .

The trends of Industrial Sector Productivity in Nigeria measured by the industry value added from the year 1991 to 2014 is illustrated in Figure 1. The trend in the values of the variable is that of a rising pattern, increasing sharply at one time and slightly at other times. Between the years 1991 and 1998, a slightly stable trend was observed until after this period when a sharp decline, though temporary, was observed. Following this period, the Industry Value Added increased sharply in the year 2002 and ever since then, the rising trend has continued. Though on a fluctuating pattern, the rising trend continued till the last years of the period under study. 


\section{Figure 1 Industry Value Added}

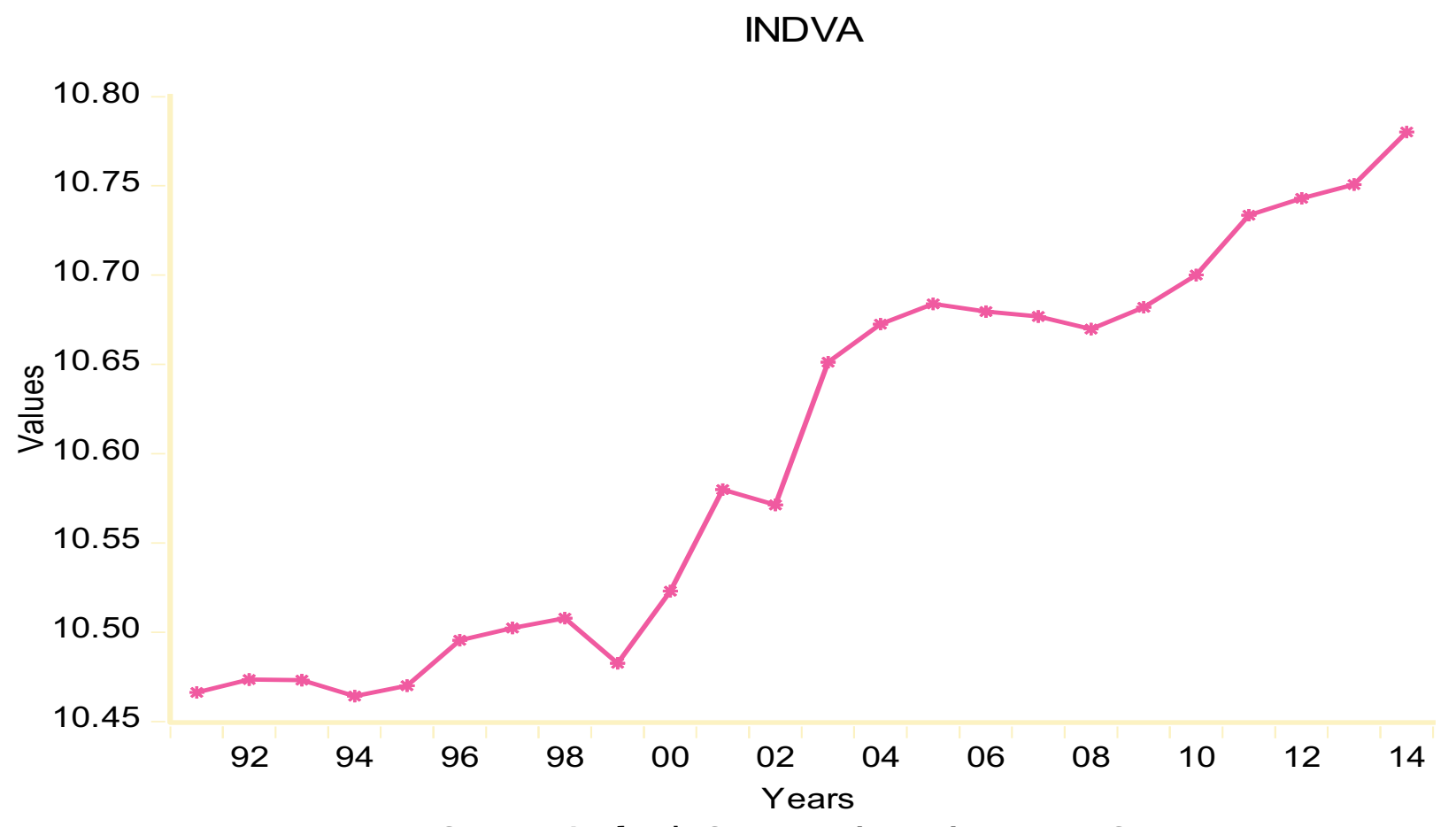

Source: Author's Computation using EVIEWS

The various factors/variables accounting for the observed trend in the Industrial Sector Productivity in Nigeria include access to power supply, improved sanitation, water supply and the literacy levels. These are discussed explicitly below.

Table 3 Descriptive Statistics

\begin{tabular}{lccccc}
\hline STATISTICS & ELEC & INDVA & SANF & GER & WATRS \\
\hline \hline Mean & 32.05440 & 10.60136 & 33.23750 & 88.94872 & 54.69167 \\
Median & 34.27287 & 10.61550 & 33.10000 & 89.26272 & 54.80000 \\
Maximum & 41.86490 & 10.78020 & 37.70000 & 106.4835 & 67.60000 \\
Minimum & 19.71365 & 10.46420 & 29.30000 & 68.75525 & 41.20000 \\
Std. Dev. & 6.993855 & 0.109823 & 2.579655 & 9.846113 & 8.184870 \\
Skewness & -0.407259 & 0.043057 & 0.126242 & -0.240724 & -0.042387 \\
Kurtosis & 1.701282 & 1.432393 & 1.806775 & 2.300499 & 1.771686 \\
Jarque-Bera & 2.350109 & 2.464806 & 1.487534 & 0.721094 & 1.515941 \\
Probability & 0.308802 & 0.291591 & 0.475320 & 0.697295 & 0.468617 \\
Sum & 769.3056 & 254.4326 & 797.7000 & 2134.769 & 1312.600 \\
Sum Sq. Dev. & 1125.022 & 0.277404 & 153.0563 & 2229.757 & 1540.818 \\
Observations & 24 & 24 & 24 & 24 & 24 \\
\hline \hline
\end{tabular}

Source: Author's Computation

The table 3 describes the statistics of the study. Results as presented in the table reveal the mean/average values of the variables. The (ELEC) Electricity Production from Hydroelectric Sources had a mean value of $32.05+/-6.99$, meaning that on the average, electricity production from hydroelectric sources was about $32 \%$ of total electricity production. The Proportion of Population with Access to Improved Sanitation Facilities (SANF) was about 33\% on the average at a maximum of about 38\%. Also, the Proportion of Population with Access to Improved Water Sources (WATRS) was $55 \%$ on the average and a minimum of $41 \%$. For the Gross Primary Enrolment Ratio (GER), the mean value was $88.9 \%+/-9.85$. This variable has 
its minimum and maximum values as $68.76 \%$ and $106.48 \%$ respectively. The table further shows the deviations from the mean as well as the maximum and minimum values for the other data gathered for this study. The coefficient of skewness for all the variable data are below one (1) signifying a normal frequency distribution for all the variables. Kurtosis coefficient are 1.70 (ELEC), 1.43 (INDVA), 1.807 (SANF), 2.300 (GER) and 1.772 (WATRS). Jarque-Bera statistic shows that all the variables have insignificant p-values. Both Kurtosis and Jarque-Bera statistic confirm that the time series data were normally distributed. Hence, the data are suitable for analysis on parametric considerations, particularly in estimating the OLS regression model.

\section{Inferential Analysis of Results \\ Unit Root Test}

Unit root test was conducted on the panel data to avoid spurious regression which tends to accept a false relationship or reject a true relationship as a result of the use of non-stationary data for the analysis. The Augmented Dickey Fuller (ADF) procedure was adopted in testing for existence of unit root in the panel data and the order of integration of all the variables.

Since a spurious regression is not desirable, testing for stationarity is a prerequisite when working with panel data. This transforms the non-stationary data into stationary data by means of differencing. The results of the Unit Root Test are summarized in the table 4 below;

Table 4 Augmented Dickey Fuller Unit Root Test

\begin{tabular}{|c|c|c|c|c|c|c|c|}
\hline \multirow{2}{*}{ Variables } & \multicolumn{3}{|c|}{ Test Critical Values } & \multirow[t]{2}{*}{ At Level } & \multirow{2}{*}{$\begin{array}{c}\text { At First } \\
\text { Difference }\end{array}$} & \multirow{2}{*}{$\begin{array}{l}\text { At Second } \\
\text { Difference }\end{array}$} & \multirow{2}{*}{$\begin{array}{c}\text { Order of } \\
\text { Integration }\end{array}$} \\
\hline & $1 \%$ & $5 \%$ & $10 \%$ & & & & \\
\hline ELEC & -3.7696 & -3.0049 & -2.6422 & - & $\begin{array}{c}-4.7924 \\
(0.0010)\end{array}$ & - & I (1) \\
\hline INDVA & -3.7696 & -3.0049 & -2.6422 & - & $\begin{array}{c}-4.5882 \\
(0.0016)\end{array}$ & - & I (1) \\
\hline SANF & -3.7696 & -3.0049 & -2.6422 & $\begin{array}{c}-5.9987 \\
(0.0001)\end{array}$ & & - & I $(-)$ \\
\hline GER & -5.9987 & -5.9987 & -5.9987 & - & $\begin{array}{c}-4.1250 \\
(0.0045) \\
\end{array}$ & - & I (1) \\
\hline WATRS & -3.7529 & -2.9981 & -2.6388 & $\begin{array}{c}-4.4992 \\
(0.0018)\end{array}$ & - & - & I $(-)$ \\
\hline
\end{tabular}

P-values at 5\% statistical significance

Results as presented in the table 4 show that the ELEC, INDVA and GER have unit roots (i.e. not stationary) at levels. However, the SANF and WATRS are stationary at levels, meaning that we rejected the null hypothesis at level which states that they have unit root. By first differencing, ELEC, INDVA and GER, however, were all stationary. This means that for these variables, we accepted the null hypothesis at level which states that they have unit root, but rejected the null hypothesis at first difference. All were stationary at second difference, indicating the absence of unit root in the variable data. Having tested for stationarity therefore, the time series data are suitable for analysis.

\section{Co-Integration Test}

The result of the Johansen's co-integration test is given below in Table 5. There are two methods displayed in the table above, the trace statistics and Max Eigen-statistic. Trace statistic agreed that there are two (2) co-integrating equations. This is confirmed with the 
rejection of the null hypothesis at 5\% level while also the z-test assumes there is two (2) cointegrating equation owing to the p-values $(0.0001$ and 0.0226$)$ being less than 0.05 level.

Table 5: Johansen's Co-Integration Test

\begin{tabular}{|c|c|c|c|c|}
\hline \multicolumn{5}{|c|}{ Unrestricted Cointegration Rank Test (Trace) } \\
\hline $\begin{array}{l}\text { Hypothesized } \\
\text { No. of CE(s) }\end{array}$ & Eigenvalue & $\begin{array}{c}\text { Trace } \\
\text { Statistic }\end{array}$ & $\begin{array}{c}0.05 \\
\text { Critical Value }\end{array}$ & Prob.** \\
\hline None $*$ & 0.914581 & 126.4773 & 69.81889 & 0.0000 \\
\hline At most $1 *$ & 0.864676 & 72.35307 & 47.85613 & 0.0001 \\
\hline At most 2 & 0.429203 & 28.35123 & 29.79707 & 0.0727 \\
\hline At most $3 *$ & 0.388499 & 16.01534 & 15.49471 & 0.0417 \\
\hline At most $4^{*}$ & 0.210323 & 5.194893 & 3.841466 & 0.0226 \\
\hline \multicolumn{5}{|c|}{$\begin{array}{l}\text { Trace test indicates } 2 \text { cointegratingeqn(s) at the } 0.05 \text { level } \\
* \text { denotes rejection of the hypothesis at the } 0.05 \text { level } \\
\text { **MacKinnon-Haug-Michelis (1999) p-values }\end{array}$} \\
\hline \multicolumn{5}{|c|}{ Unrestricted Cointegration Rank Test (Maximum Eigenvalue) } \\
\hline $\begin{array}{l}\text { Hypothesized } \\
\text { No. of CE(s) }\end{array}$ & Eigenvalue & $\begin{array}{l}\text { Max-Eigen } \\
\text { Statistic }\end{array}$ & $\begin{array}{l}0.05 \\
\text { Critical Value }\end{array}$ & Prob.** \\
\hline None ${ }^{*}$ & 0.914581 & 54.12421 & 33.87687 & 0.0001 \\
\hline At most $1^{*}$ & 0.864676 & 44.00183 & 27.58434 & 0.0002 \\
\hline At most 2 & 0.429203 & 12.33589 & 21.13162 & 0.5149 \\
\hline At most 3 & 0.388499 & 10.82045 & 14.26460 & 0.1634 \\
\hline At most $4^{*}$ & 0.210323 & 5.194893 & 3.841466 & 0.0226 \\
\hline \multicolumn{5}{|c|}{$\begin{array}{l}\text { Max-eigenvalue test indicates } 2 \text { cointegratingeqn(s) at the } 0.05 \text { level } \\
* \text { denotes rejection of the hypothesis at the } 0.05 \text { level } \\
* * \text { MacKinnon-Haug-Michelis (1999) p-values }\end{array}$} \\
\hline
\end{tabular}

Source: Author's Computation using EVIEWS

From the findings, we see that the two tests agreed that there are two (2) co-integrating equations. Since we are interested in establishing just one co-integrating equation which embodies the dependent variable (INDVA) and the rest of the other independent variables, the regression equation is estimated below.

The regression equation of the relationship between Human Capital Development, Infrastructural Development and the Industrial Sector Productivity in Nigeria is:

$$
\text { 'INDVA }=-6.2628+0.1136 \text { WATRS }+0.0023 G E R+0.3131 S A N F+0.0013 E L E C
$$

This model establishes the empirical relationship between human capital development (Gross Primary Enrolment Ratio), Infrastructural development (access to power supply, potable water and sanitation facilities) and the Industrial Sector Productivity proxied by the industry value added. 
Dependent Variable: INDVA

Table 6 Regression Analysis Result

Method: Least Squares

Date: 04/17/16 Time: 23:05

Sample: 19912014

Included observations: 24 (after adjustments)

\begin{tabular}{crlrr}
\hline \hline \multicolumn{1}{c}{ Variable } & Coefficient & Std. Error & t-Statistic & Prob. \\
\hline \hline ELEC (1) & 0.001334 & 0.001702 & 0.783592 & 0.4429 \\
SANF & 0.313112 & 0.063150 & 4.958222 & 0.0001 \\
GER (1) & 0.002285 & 0.000608 & 3.761230 & 0.0013 \\
WATRS & 0.113565 & 0.020471 & 5.547487 & 0.0000 \\
C & -6.262767 & 3.259621 & -1.921318 & 0.0698 \\
\hline \hline R-squared & 0.973832 & Mean dependent var & 10.60136 \\
Adjusted R-squared & 0.968323 & S.D. dependent var & 0.109823 \\
S.E. of regression & 0.019546 & Akaike info criterion & -4.849008 \\
Sum squared resid & 0.007259 & Schwarz criterion & -4.603580 \\
Log likelihood & 63.18810 & Hannan-Quinn criter. & -4.783896 \\
F-statistic & 176.7691 & Durbin-Watson stat & 1.743544 \\
Prob(F-statistic) & 0.000000 & & \\
\hline \hline
\end{tabular}

\section{Source: Author's Computation}

The intercept of the equation is -6.2628US\$. This (constant) represents the value of the industry value added (INDVA)in Nigeria if human capital and infrastructural development were zero. This means that in the absence of human capital and infrastructural development, the industrial sector productivity in Nigeria would be negative.

Results showed that the coefficient of the Percent of Electricity Production from hydroelectric sources (ELEC) was 0.0013 , having a t-statistic value of 0.7836 at $\mathrm{p}=0.4429$. This means that a unit increase in ELEC should result in about $0.0013(0.13 \%)$ positive changes in the industrial sector productivity. However, since its p-value is not less than 0.05 , it is concluded that the ELEC is not a good predictor of the Industrial Sector Productivity, this collaborates the work of Anochinwa et al (2014). Furthermore, Access to Improved Sanitation Facilities (SANF) had a coefficient of 0.3131 and t-statistic 4.9582 at $\mathrm{p}=0.0001$. This variable is a significant predictor of Industrial Productivity and a unit increase in access to sanitation facilities will significantly lead to about $31 \%(0.3131 * 100)$ positive changes in industrial productivity. The other variables that have significant positive effects on Industrial Sector Productivity are Gross Primary Enrolment Ratio (GER) and Access to Improved Water Supply (WATRS) contributing about $0.23 \%$ and $11 \%$ respectively to Industrial Productivity. These variables are significant predictors of industry value added.

The R-squared value of this model is 0.9738 . This means that the independent variables (Human Capital and Infrastructures) accounted for about 97\% (0.9738*100) of variations in Industrial Sector Productivity. The remaining 3\% $(1-0.9738)$ is due to error factors, determined by other variations not covered in this model.

The F-statistic shows overall significance of model. The F-statistic is significant at $5 \%$ level since the probability of its value $(0.000000)$ is less than the 0.05 critical level. 
We therefore conclude that Human Capital (particularly, the social infrastructural factors access to clean waters and access to improved sanitization facilities) cum economic infrastructure have significant effects on Industrial Sector Productivity in Nigeria. The more the people having access to improved water supply, improved sanitation facilities, access to education, and probably access to electricity the more the industrial productivity in Nigeria.

The Durbin-Watson statistic which equals 1.74 shows the absence of serial autocorrelation. This means that there is independence of observation among the regressors independent of the error terms. It indicates independence of observations or no autocorrelation.

\section{CONCLUSION}

This study examined relationship that exists in human capital development, infrastructure and industrial sector productivity in Nigeria. The periods covered for the study was between 1991 and 2014. We further analysed that human capital development variables include access to education (gross primary school enrolment), access to clean water and improved sanitization facilities while infrastructure is measured by electricity production from hydroelectric source. Our regression estimate revealed that human capital development has positive and significant effect on the industrial sector productivity (using Industry value added as proxy) while infrastructure, although has positive but insignificant effect on the productivity sector in Nigeria.

The result from this study reflects some improvement efforts of Nigeria government in attaining some of the Millennium Development Goals, ranging from increasing net enrolment rate in basic education in primary schools, reduction of maternal and child mortality that may result in increased capacity for human capital, access to safe drinking water and slightly improvement in sanitization facilities in the country since 2005.

Nevertheless, the study held that higher productivity in industrial sectors of Nigerian economy is explained significantly by improved level of sanitization facilities, access to clean water and increasing enrolment of pupils in primary schools while infrastructures are also positively related but insignificant.

\section{Policy Recommendation}

Having established that human capital development and infrastructures have positive effect on industrial sectors' productivity in Nigeria, the study thereby recommends the following policy measures to achieve increased level of productivity in the country:

1. Government at both federal and state level should consider effective negotiation of debt relief from Paris Club and other foreign debts which will enable them to save more funds for public investment, hence, meaningful pro-poor intervention programmes and projects;

2. Effective implementation of annual and supplementary budgets cum independent evaluation of post implementation budget as this will enable the country to actualize target audience and avoid misappropriation of funds for unintended purpose;

3. Affordable and quality basic education, health facilities and safe drinking water should be an uncompromised projects of the government and possible total health insurance scheme;

4. Transparency in governance which will guarantee unsolicited cooperation from all tax payers( potential tax payers included) hence, increase government revenue towards meeting various pro-poor intervention programmes and projects; 


\section{Reference}

Adesoye A Bolaji (2014) "Infrastructural Financing in Nigeria: Growth Implications" Journal of Economics and Sustainable Development www.iiste.orgISSN 2222-1700 (Paper) ISSN 2222-2855 (Online) Vol.5, No.5, 2014

Akintoye V. A., Phillip A. O., and Opeyemi O. A. (2013) "The Role of Human Capital in Industrial development: The Nigerian Case (1980-2010),"Modern Economy, 2013, 4, 639-651http://dx.doi.org/10.4236/me.2013.410069

Anders Isaksson (2009), "Public Capital, Infrastructure and Industrial Development," Research and Statistics branch Working Paper 15/2009.

Anochiwa L.I., and Maduka A. (2014) "Human Capital, Infrastructure and Economic Growth in Nigeria: An Empirical Evidence," IOSR Journal of Electrical and Electronics Engineering (IOSR-JEEE) e-ISSN: 2278-1676,p-ISSN: 2320-3331, Volume 9, Issue 4 Ver. VI (Jul - Aug. 2014), PP 01-06 www.iosrjournals.org www.iosrjournals.org

Antonio E., and Gregoire G (2012) “The Impact of Infrastructure on Growth in Developing Countries" IFC Economics Notes, Note 1.

Ben. U. Omojimite (2011) "Building Human Capital for Sustainable Economic Development in Nigeria” Journal of Sustainable Development Vol. 4, No. 4; August 2011

Bongani, R.Q., and Fyth R (2013) "Human Capital for Quality Infrastructure Development in South Africa: A project-Based Pedagogical Analysis," Journal of Social and Development Sciences Vol. 4, No. 6, pp. 278-285

Chete L.N., Adeoti J. O.,Adeyinka F. M., and Ogundele O (2013) "Industrial Development and Growth in Nigeria: Lessons and Challenges," Nigerian Institute of Social and Economic Research (NISER), Ibadan,

Crook T., R., Todd S., Y., James G. Combs J., G., Woehr D., J., and Ketchen D., J “Does Human Capital Matter? A MetaAnalysis of the Relationship Between Human Capital and Firm Performance" (2011) Journal of Applied Psychology 2011, Vol. 96, No. 3, 443-456

Edun A. O., Akinde J. O., and Olaleye S. O. (2013) "Infrastructural Development and Its Effect on Economic Growth: The Nigerian Perspective," European Scientific Journal November 2013 edition vol.9, No.31

Emeka Emmanuel Okafor (2008) "Development Crisis of Power Supply and Implications for Industrial Sector in Nigeria" Stud Tribes Tribals, 6(2): 83-92 (2008)

Georges D. Mbondo (2014) "Public Spending on Infrastructures and Productive Efficiency in Sub-SaharanAfrica: An Analysis from the Stochastic Production Frontier on Panel Data" Journal of International Business and Economics June 2014, Vol. 2, No. 2, pp.

Geraldine N.O., and Ogwude I., C., (2012) "Relationship between Human Resource Effects and Productivity in the Nigerian Transport Industry" British Journal of Science 67 July 2012, Vol. 6 (1)

Heino Bohn Nielsen (2005) "Generalized Method of Moments (GMM) Estimation" Econometrics 2 - Fall 2005.

Jaiso R., A., Ishita D., and Todd M., G (2011) "Productivity and the Density of Human Capital" Staff Report No. 440 Revised September 2011.

Marimuthu M., Arokiasamy L., and Ismail M. (2009) "Human Capital development and Its Implication on Firm Performance: Evidence from Developmental Economics," Uluslararası Sosyal Ara_tırmalar Dergisi the Journal of International Social Research Volume 2 / 8 summer 2009.

Nedozi F., O., Obasanmi J., O., and Ighata J., A (2014) "Infrastructural Development and Economic Growth in Nigeria: Using Simultaneous Equation" J Economics, 5(3): 325-332 (2014)

Olayinka M., U., and Uwalomwa U (2011) "Intellectual Capital and Business Performance: Evidence from Nigeria" Interdisciplinary Journal of Research in Business Vol. 1, Issue. 10, (pp.49- 56) November, 2011

Oyinlola O. M. and Adeyemi A. Z. (2014) "An Empirical Analysis of Human Capital development and Organizational Performance in banking Sector: A Nigerian Experience," International Journal of Economics, Commerce and management united Kingdom Vol. II, Issue 7, 2014

Simon-Oke O. Olayemi (2012) "Human Capital Investment and Industrial Productivity in Nigeria, "International Journal of Humanities and Social Science Vol. 2 No. 16 [Special Issue - August 2012]

Srinivasu, B and P. Srinivasa Rao (2013) Infrastructure Development and Economic growth: Prospects and Perspective, Journal of Business Management \& Social Sciences Research (JBM\&SSR) Volume 2, No.1, 81 - 91

Tawose Joseph (2012) "Effects of Public Expenditure on Industrial Sector Productivity in Nigeria," Canadian Social Science Vol. 8, No. 1, 2012, pp. 204-214

Todaro, M.P. and Smith, S.C. (2011). Economic development (11 thed.). Boston, MA: Addison-Wesley. 
Vijayamohanan Pillai N (2008) “Infrastructure, Growth and Human Development in Kerala," centre for development studies, Prasanth Nagar, Ullor, Trivandrun, Kerala, India.

World Bank (2016), World Development Indicators, 2016 Washington, D.C.: World Bank.

http://data.worldbank.org/news/world-development-indicators-2016 (Accessed April 17, 2016) 